\title{
Clinical challenges in the molecular characterization of circulating tumour cells in breast cancer
}

\author{
E S Lianidou*,1, D Mavroudis ${ }^{2}$ and V Georgoulias ${ }^{2}$ \\ ${ }^{1}$ Analysis of Circulating Tumor Cells Lab, Lab of Analytical Chemistry, Department of Chemistry, University of Athens, \\ 15771 Athens, Greece and 'Laboratory of Tumor Cell Biology, Medical School, University of Crete, Heraklion, Greece
}

Blood testing for circulating tumour cells (CTC) has emerged as one of the hottest fields in cancer research. CTC detection and enumeration can serve as a 'liquid biopsy' and an early marker of response to systemic therapy, whereas their molecular characterisation has a strong potential to be translated to individualised targeted treatments and spare breast cancer (BC) patients unnecessary and ineffective therapies. Different analytical systems for CTC detection and isolation have been developed and new areas of research are directed towards developing novel assays for CTC molecular characterisation. Molecular characterisation of single CTC holds considerable promise for predictive biomarker assessment and to explore CTC heterogeneity. The application of extremely powerful next-generation sequencing technologies in the area of CTC molecular characterisation in combination with reliable single CTC isolation opens new frontiers for the management of patients in the near future. This review is mainly focused on the clinical potential of the molecular characterisation of CTC in BC.

The presence of disseminated tumour cells (DTCs) in bone marrow (BM) and lymph nodes, and circulating tumour cells (CTC) in peripheral blood has been linked with worse prognosis and early relapse in breast cancer (BC) in numerous clinical studies. Recently, blood testing for CTC has emerged as one of the hottest fields in cancer research. CTC enumeration can serve as a 'liquid biopsy' and an early marker of response to systemic therapy, whereas their molecular characterisation has a strong potential to be translated to individualised targeted treatments and spare BC patients unnecessary and ineffective therapies (Lianidou et al, 2012). The aims of research on CTC include (a) estimation of the risk for metastatic relapse or metastatic progression, (b) patient stratification and real-time monitoring of treatment efficacy, (c) identification of therapeutic targets and resistance mechanisms, and (d) understanding metastasis development in cancer patients (Pantel et al, 2009). Different analytical systems for CTC isolation and detection have been developed and new areas of research are directed towards developing novel assays for CTC molecular characterisation (Alix-Panabières and Pantel, 2013). There is, however, substantial variability in the rates of positive samples using existing detection techniques. This lack of standardisation of technology hampers the implementation of CTC measurement in clinical routine practice. Direct comparison of different methodologies for detecting CTC in blood samples from patients with $\mathrm{BC}$ has revealed a substantial variation in the detection rates (Van der Auwera et al, 2010; Strati et al, 2013). Moreover, many questions still remain unanswered regarding the biology of CTC, the optimal method to enumerate and characterise them, and the path to regulatory and general clinical acceptance of technology platforms currently under development (Parkinson et al, 2012). This review is mainly focused on the clinical potential of the molecular characterisation of CTC in BC.

\section{CLINICAL RELEVANCE OF CTC IN BC}

The American Joint Committee on Cancer has recently proposed a new category, $\mathrm{M} 0(\mathrm{i}+)$, for TNM staging in BC defined as 'no clinical or radiographic evidence of distant metastases, but deposits of molecularly or microscopically detected tumour cells (no larger than $0.2 \mathrm{~mm}$ ) in blood, BM, or other non-regional nodal tissue in a patient without symptoms or signs of metastases'. Very recently, the first comprehensive meta-analysis of published literature on the prognostic relevance of CTC clearly indicated that the detection of

*Correspondence: Dr ES Lianidou; E-mail: lianidou@chem.uoa.gr 
CTC is a reliable prognostic factor in patients with early-stage and metastatic BC (MBC) (Zhang et al, 2012).

\section{DUCTAL CARCINOMA IN SITU}

According to the prevailing model for systemic cancer progression, metastasis is a late event, and cancer progresses within the primary tumour before metastatic dissemination of fully malignant cells. However, Braun et al (2000) showed many years ago that tumour cells can disseminate early during tumour progression, whereas Pantel and Brakenhoff (2004) claimed that 'immature' tumour cells can leave the primary tumour early during tumour progression. Klein (2009) proposed a second model that draws together data from disease courses, tumour growth rates, autopsy studies, clinical trials and molecular genetic analyses of primary and DTCs. This model posits a parallel, independent progression of metastases arising from early DTCs (Klein, 2009).

Only invasive cancers are assumed to shed isolated tumour cells into the bloodstream and infiltrate lymph nodes. However, latest studies indicate that tumour cell dissemination may occur before stroma invasion, that is, in ductal carcinoma in situ (DCIS). Either these cells have already started to disseminate from pre-invasive mammary lesions or from occult invasive tumours, or represent the earliest step of microinvasion in a pre-invasive lesion (Banys et al, 2012; Sänger et al, 2011). The clinical relevance of these cells has to be further evaluated.

\section{EARLY BC}

In early $\mathrm{BC}$, our group has shown many years ago the prognostic value of CTC in the same cohort of patients before, during and after chemotherapy (Xenidis et al, 2006, 2007, 2009). Benoy et al (2006) compared the prognostic value of DTCs and CTC in early $\mathrm{BC}$ and came to the conclusion that only the presence of DTCs was highly predictive for overall survival (OS). Bidard et al (2010) prospectively detected CTC using the CellSearch system before and after neoadjuvant chemotherapy in a phase II trial and reported that detection of one or more CTC in $7.5 \mathrm{ml}$ of blood before neoadjuvant chemotherapy can accurately predict OS.

Persistent detection of CTC during the first 5 years of follow-up was associated with an increased risk of late disease relapse and death in patients with operable BC, and indicated the presence of chemotherapy- and hormonotherapy-resistant residual disease (Saloustros et al, 2011). Lucci et al (2012) prospectively collected data on CTC at the time of definitive surgery from chemo-naive patients with stage 1-3 BC and found that the presence of one or more CTC predicted for early recurrence and decreased OS.

These studies suggest that analysis of CTC might serve as a clinically useful monitoring tool and should be tested as an indicator for secondary adjuvant treatment intervention within clinical trials. A summarised outline of the clinical relevance of CTC in early BC is shown in Table 1.

\section{METASTATIC BC}

In their seminal NEJM paper in 2004, Cristofanilli et al (2004) have clearly shown that CTC represent an independent prognostic factor for PFS and OS in patients with MBC. Giordano et al (2012) analysed the relationship between CTC and OS in immunohistochemically defined primary tumour molecular subtypes and report that the risk of death increased linearly with increasing CTC counts in all molecular tumour subtypes, but was higher in oestrogen receptor $(\mathrm{ER})+$ and triple-negative $\mathrm{MBC}$ than in
HER2 + . CTC' prognostic effect was less evident in HER2 + MBC patients treated with targeted therapy. This study may support the concept that the number of CTC, along with their biological characteristics, needs to be carefully considered in future analyses (Giordano et al, 2012).

The same group explored the predictive value of baseline CTC in patients receiving different treatments. After a median follow-up of 18 months, the CTC count was confirmed to be a robust prognostic marker for the overall population, whereas in patients with HER-2-overexpressed and/or -amplified tumours receiving trastuzumab or lapatinib the baseline CTC count was not prognostic. Furthermore, in patients with HER-2 normal tumours, a baseline CTC count $\geqslant 5$ identified patients who derived benefit from more aggressive treatments, including combination chemotherapy and chemotherapy, plus bevacizumab. This analysis suggests that the prognostic information provided by the CTC count may be useful in patient stratification and therapy selection, particularly for the group with positive CTC detection in which various therapeutic choices may procure differential palliative benefit (Giuliano et al, 2011). In patients with $\mathrm{MBC}$ in whom no CTC were found or in whom CTC were eliminated during treatment, the OS rate differed significantly from that of patients with persistent CTC (Tewes et al, 2009).

However, although there is a multitude of assays for the detection of CTC, only a very limited number of studies compared the clinical relevance of results obtained with different methods. The results of the DETECT trial, which was designed to directly compare the prognostic value of two commercially available CTC assays in MBC, have shown that the prognostic relevance of CTC detection depends on the test method (Muller et al, 2012). Elevated CTC before the second cycle of therapy was an early predictive marker of poor PFS and OS, and could be used to monitor treatment benefit, whereas CTC decrease under treatment was stronger with targeted therapy (Pierga et al, 2012). The detection of CTC in patients with MBC before frontline therapy could define a subgroup of patients with dismal clinical outcome (Androulakis et al, 2012).

A summarised outline of the clinical relevance of CTC in MBC is shown in Table 2 .

\section{CLINICAL TRIALS INVOLVING CTC}

The clinical relevance of CTC can only be established through clinical trials specifically designed to evaluate CTC as biomarkers of response to therapy, and the association of CTC enumeration with complete response, partial response, stable disease and progressive disease (Parkinson et al, 2012). The main objectives of ongoing trials with CTC are as follows: (a) to phenotype persisting tumour cells, (b) to evaluate the benefits of secondary treatment intervention and (c) to evaluate the survival benefit from additional adjuvant treatment in high-risk patients. The main clinical perspective is to achieve more individualised treatment with improved efficacy and less side effects. A critical question is whether the CTC clearance can be used as a 'surrogate' marker for potentially improved survival for regulatory purposes. In the official website of the National Institutes of Health, a search (November 2012) on clinical studies, based on the keyword 'circulating tumour cells', revealed 479 ongoing clinical studies, whereas the combination 'circulating tumour cells and breast cancer' revealed 116 ongoing clinical studies. These trials have different designs in various patient populations, but are expected to be the pivotal trials for CTC implementation in the routine management of $\mathrm{BC}$ patients. The numerous ongoing trials that evaluate CTC as markers for early prediction of treatment efficacy have been recently reviewed in Bidard et al (2013). 
Table 1. Clinical relevance of CTC in early BC

\begin{tabular}{|c|c|c|c|}
\hline $\begin{array}{l}\text { Method } \\
\text { for CTC } \\
\text { detection }\end{array}$ & Number of patients & Clinical relevance - conclusions & References \\
\hline $\begin{array}{l}\text { RT-qPCR for } \\
\text { CK-19 mRNA }\end{array}$ & $\begin{array}{l}167 \text { Node-negative BC patients before the initiation of any } \\
\text { systemic adjuvant therapy }\end{array}$ & $\begin{array}{l}\text { Multivariate analysis revealed that detection of peripheral } \\
\text { blood CK-19 mRNA-positive cells was associated with early } \\
\text { clinical relapse }(P<0.00001) \text { and disease-related death } \\
(P=0.008) \text {. }\end{array}$ & $\begin{array}{l}\text { Xenidis et al, } \\
2006\end{array}$ \\
\hline $\begin{array}{l}\text { RT-qPCR for } \\
\text { CK-19 mRNA }\end{array}$ & $\begin{array}{l}119 \text { Patients ER/PR-positive tumours during the period of } \\
\text { tamoxifen administration }\end{array}$ & $\begin{array}{l}\text { Detection of CK-19 mRNA + cells during the administration of } \\
\text { tamoxifen was associated with an increased risk of relapse. } \\
\text { Persistency of CK-19 mRNA + cells was associated with a } \\
\text { significantly lower median disease-free interval }(P=0.0001) \\
\text { and OS }(P=0.0005) \text {. Multivariate analysis revealed that the } \\
\text { detection of CK-19 mRNA + cells during the administration } \\
\text { of tamoxifen was associated with an increased risk of relapse } \\
(H R=22.318, P=0.00006) \text { and death ( } H R=13.954 \text {, } \\
P<0.00001) \text {. }\end{array}$ & $\begin{array}{l}\text { Xenidis et al, } \\
2007\end{array}$ \\
\hline $\begin{array}{l}\text { RT-qPCR for } \\
\text { CK-19 mRNA }\end{array}$ & $\begin{array}{l}437 \text { Patients with early } \mathrm{BC} \text { before the start and after the } \\
\text { completion of adjuvant chemotherapy }\end{array}$ & $\begin{array}{l}\text { Detection of CK-19 mRNA-positive CTC in the blood after } \\
\text { adjuvant chemotherapy was an independent risk factor, } \\
\text { indicating the presence of chemotherapy-resistant residual } \\
\text { disease. DFS and OS were significantly reduced in patients with } \\
\text { detectable CK-19 mRNA-positive CTC post-chemotherapy: } \\
P<0.001 \text { and } P<0.001 \text {, respectively In multivariate analysis, } \\
\text { the detection of CK-19 mRNA-positive CTC before and after } \\
\text { adjuvant chemotherapy was an independent factor associated } \\
\text { with reduced DFS }(P<0.001) \text { and OS ( } P=0.003 \text { ). }\end{array}$ & $\begin{array}{l}\text { Xenidis et al, } \\
2009\end{array}$ \\
\hline $\begin{array}{l}\text { RT-qPCR for } \\
\text { CK-19 mRNA }\end{array}$ & $\begin{array}{l}312 \text { Women with operable } \mathrm{BC} \text { who had not experienced } \\
\text { disease relapse during the first } 2 \text { years of follow-up }\end{array}$ & $\begin{array}{l}\text { Detection of CK-19 mRNA-positive CTC during the first } 5 \text { years } \\
\text { of follow-up was associated with an increased risk of late } \\
\text { relapse and death. Multivariate analysis revealed that } \\
\text { persistently CTC-positive patients had a shorter DFS ( } P=0.001 \text { ) } \\
\text { and OS ( } P=0.001) \text {. }\end{array}$ & $\begin{array}{l}\text { Saloustros } \\
\text { et al, } 2011\end{array}$ \\
\hline $\begin{array}{l}\text { Various } \\
\text { systems }\end{array}$ & Meta-analysis (1990-2012), $n=2993$ patients & $\begin{array}{l}\text { Detection of CTC is a reliable prognosticator in patients with } \\
\text { early-stage BC; DFS: HR 2.86, } 95 \% \mathrm{Cl} 2.19-3.75 \text {; OS: HR 2.78, } \\
95 \% \mathrm{Cl} 2.22-3.48 \text {. }\end{array}$ & $\begin{array}{l}\text { Zhang et al, } \\
2012\end{array}$ \\
\hline $\begin{array}{l}\text { CellSearch } \\
\text { assay }\end{array}$ & 302 Chemo-naive patients with stage 1-3 BC & $\begin{array}{l}\text { The presence of one or more CTC predicted early recurrence } \\
\text { and decreased OS in chemo-naive patients with non-metastatic } \\
\mathrm{BC} \text {. Detection of one or more circulating tumour cells } \\
\text { predicted both decreased PFS (log-rank } P=0 \cdot 005 ; \mathrm{HR}, 4 \cdot 62 \text {; } \\
95 \% \mathrm{Cl}, 1 \cdot 79-11 \cdot 9 \text { ) and OS (log-rank } P=0 \cdot 01 ; \mathrm{HR}, 4.04 ; 95 \% \\
\mathrm{Cl}, 1 \cdot 28-12 \cdot 8 \text { ). }\end{array}$ & $\begin{array}{l}\text { Lucci et al, } \\
2012\end{array}$ \\
\hline $\begin{array}{l}\text { RT-qPCR for } \\
\text { CK-19 mRNA }\end{array}$ & $\begin{array}{l}75 \text { Women with HER2 (-) early BC and detectable CK19 } \\
\text { mRNA-positive CTC, both before and after adjuvant } \\
\text { chemotherapy median follow-up: } 67.2 \text { months }\end{array}$ & $\begin{array}{l}\text { Randomised study showed that administration of trastuzumab } \\
\text { can eliminate chemotherapy-resistant CK19 mRNA-positive } \\
\text { CTC, reduce the risk of disease recurrence and prolong the } \\
\text { DFS The median DFS was significantly higher for the } \\
\text { trastuzumab-treated patients }(P=0.008) \text {. }\end{array}$ & $\begin{array}{l}\text { Georgoulias } \\
\text { et al, } 2012\end{array}$ \\
\hline $\begin{array}{l}\text { AdnaTest } \\
\text { BreastCancer }\end{array}$ & 502 Patients & $\begin{array}{l}\text { A subset of primary BC patients shows EMT and stem cell } \\
\text { characteristics, but the currently used detection methods for } \\
\text { CTC are not efficient in identifying a subtype of CTC, which } \\
\text { underwent EMT. }\end{array}$ & $\begin{array}{l}\text { Kasimir- } \\
\text { Bauer et al, } \\
2012\end{array}$ \\
\hline
\end{tabular}

\section{MOLECULAR CHARACTERISATION OF CTC AND} INDIVIDUALISED TREATMENT

Molecular characterisation of CTC can provide important information for the identification of therapeutic targets and resistance mechanisms in these cells, as well as for the stratification of patients and real-time monitoring of systemic therapies (Lianidou et al, 2012).

\section{HER-2 AND ER/PROGESTERONE RECEPTOR STATUS} IN CTC

Hormone therapy and anti-HER-2 therapies are prescribed according to the hormone (ER/progesterone receptor (PR) expression) and HER-2 status of the primary tumour. Nonetheless, there is a growing body of evidence that the hormone receptor and HER-2 status can change over time, and especially during disease 


\begin{tabular}{|c|c|c|c|}
\hline CTC detection & Number of patients & Clinical relevance - conclusions & References \\
\hline CellSearch assay & $177 \mathrm{MBC}$ patients & $\begin{array}{l}\text { CTC represent an independent prognostic factor for PFS and OS in patients with } \\
\text { metastatic } B C \text {. The number }(\geqslant 5) \text { of CTC at baseline and at the first follow-up visit were } \\
\text { the most significant predictors of PFS and OS. }\end{array}$ & $\begin{array}{l}\text { Cristofanilli } \\
\text { et al, } 2004\end{array}$ \\
\hline $\begin{array}{l}\text { AdnaTest } \\
\text { BreastCancer }\end{array}$ & $\begin{array}{l}39 \mathrm{MBC} \text { patients }(226 \\
\text { blood samples) }\end{array}$ & $\begin{array}{l}\text { A major proportion of CTC of metastatic BC patients shows EMT and tumour stem cell } \\
\text { characteristics. }\end{array}$ & $\begin{array}{l}\text { Aktas et al, } \\
2009\end{array}$ \\
\hline $\begin{array}{l}\text { CellSearch assay vs } \\
\text { AdnaTest } \\
\text { BreastCancer }\end{array}$ & $254 \mathrm{MBC}$ patients & $\begin{array}{l}\text { The rate of BC patients with HER-2-negative primary tumours but HER-2-positive CTC } \\
\text { was } 32 \% \text { using the CellSearch and } 49 \% \text { using the AdnaTest BreastCancer. }\end{array}$ & $\begin{array}{l}\text { Fehm et al, } \\
2010\end{array}$ \\
\hline CellSearch assay & $\begin{array}{l}235 \mathrm{MBC} \text { patients median } \\
\text { follow-up: } 18 \text { months }\end{array}$ & $\begin{array}{l}\text { The prognostic information provided by CTC count may be useful in patient stratification } \\
\text { and therapy selection, particularly in the CTC-positive group, in which various therapeutic } \\
\text { choices may procure differential palliative benefit. }\end{array}$ & $\begin{array}{l}\text { Giuliano } \\
\text { et al, } 2011\end{array}$ \\
\hline CellSearch assay & $517 \mathrm{MBC}$ patients & $\begin{array}{l}\text { Risk of death increased linearly with increasing CTC count in all molecular tumour } \\
\text { subtypes, but was higher in ER }+ \text { and triple-negative MBC than in HER2 }+. C^{\prime} C^{\prime} \\
\text { prognostic effect was less evident in HER2 }+M B C \text { patients treated with targeted therapy. }\end{array}$ & $\begin{array}{l}\text { Giordano } \\
\text { et al, } 2012\end{array}$ \\
\hline $\begin{array}{l}\text { Double } \\
\text { immunofluorescence } \\
\text { (Ariol system) }\end{array}$ & $\begin{array}{l}25 \mathrm{MBC} \text { and } 25 \text { early } \\
\mathrm{BC} \text { patients }\end{array}$ & $\begin{array}{l}\text { CTC expressing Twist and vimentin, suggestive of EMT, were identified. EMT is involved } \\
\text { in the metastatic potential of CTC. }\end{array}$ & $\begin{array}{l}\text { Kallergi } \\
\text { et al, } 2011\end{array}$ \\
\hline Various systems & $\begin{array}{l}\text { Meta-analysis } \\
(1990-2012), n=3069\end{array}$ & $\begin{array}{l}\text { Detection of CTC is a reliable prognosticator in patients with metastatic BC: PFS: HR 1.78, } \\
95 \% \mathrm{Cl} 1.52-2.09 ; \mathrm{OS}: \mathrm{HR} 2.33,95 \% \mathrm{Cl} 2.09-2.60 \text {. }\end{array}$ & $\begin{array}{l}\text { Zhang et al, } \\
2012\end{array}$ \\
\hline $\begin{array}{l}\text { CellSearch and } \\
\text { AdnaTest Breast } \\
\text { Cancer }\end{array}$ & 254 MBC patients & $\begin{array}{l}\text { The prognostic relevance of CTC detection in metastatic BC patients depends on the test } \\
\text { method. }\end{array}$ & $\begin{array}{l}\text { Muller et al, } \\
2012\end{array}$ \\
\hline CellSearch assay & $267 \mathrm{MBC}$ patients & $\begin{array}{l}\text { Elevated CTC before the second cycle was an early predictive marker of poor PFS and } \\
\text { OS, and could be used to monitor treatment benefit CTC decrease under treatment was } \\
\text { stronger with targeted therapy. }\end{array}$ & $\begin{array}{l}\text { Pierga et al, } \\
2012\end{array}$ \\
\hline
\end{tabular}

recurrence or progression in BC patients (Fehm et al, 2009, 2010; Tewes et al, 2009; Punnoose et al, 2010; Riethdorf et al, 2010; Ignatiadis et al, 2011; Sieuwerts et al, 2011). In this context, re-evaluation of hormone receptor and HER-2 status by molecular characterisation of CTC is a strategy with potential clinical application. An optimal individualised treatment could then be selected by characterising ER and HER-2 status in CTC and comparing it with the primary tumour (Rack et al, 2012). Ligthart et al (2013) have recently developed an automated algorithm for evaluating HER-2 expression in CTC when using the CellSearch system. They reported that HER-2 expression is very heterogeneous among CTC within each patient.

We have recently investigated in a randomised study the effect of trastuzumab on patients' clinical outcome. For this reason, women with HER-2-negative early BC and detectable CK-19positive CTC before and after adjuvant chemotherapy were randomised to receive either trastuzumab or observation. According to our findings, the administration of trastuzumab can eliminate chemotherapy-resistant CK-19-positive CTC, reduce the risk of disease recurrence and prolong disease-free survival (DFS) (Georgoulias et al, 2012).

HER-2-positive CTC were also detected in DCIS/LCIS or M0 BC irrespective of the primary tumour HER-2 status, but their presence was more common in women with HER-2-positive disease (Ignatiadis et al, 2011). In a prospective study, HER-2positive CTC were detected in a relevant number of patients with HER-2-negative primary tumours. It is interesting to note that the rate of BC patients with HER-2-negative primary tumours but HER-2-positive CTC, was 32\% using the CellSearch and $49 \%$ using the AdnaTest BreastCancer assay. On the basis of these findings, it would be interesting and of potential clinical value to correlate the assay-dependent HER-2 status of CTC to the clinical response on HER-2-targeted therapies (Fehm et al, 2010).

According to the same investigators, the biology of the primary tumour seems to direct the spread of CTC. When blood of 431 patients with primary BC were analysed for EpCAM, MUC1 and HER-2 transcripts with the AdnaTest BreastCancer assay, discordant HER-2/ER/PR receptor expression on CTC was reported as compared with that on the primary tumour. When expression of the ER and PR was also assessed in an additional RT-PCR, it was found that most of the CTC were 'triple-negative'. When BM aspirates from the same patients were analysed for DTC by immunocytochemistry, there was a weak concordance between CTC and DTCs. As the expression profile between CTC and the primary tumour differs, the consequence for the selection of adjuvant treatment has to be evaluated (Fehm et al, 2009).

Rack et al (2012) tested the efficacy of trastuzumab in clearing HER-2-positive, isolated tumour cells from the BM of patients completing primary treatment. According to their findings, trastuzumab is effective in clearing HER-2-positive cells from the BM during recurrence-free follow-up of BC patients. Given the heterogeneity of minimal residual disease (MRD), these patients might benefit from a combination of targeted treatment approaches.

When $C K$-19-positive CTC were prospectively and longitudinally detected in patients with ER/PR-positive tumours during the period of tamoxifen administration, multivariate analysis revealed that the detection of CK-19-positive CTC during the administration of tamoxifen was associated with an increased risk of relapse (Xenidis et al, 2007). 
EPITHELIAL-MESENCHYMAL TRANSITION, DORMANCY AND STEM CELL MARKERS

The persistence of CTC in BC patients might be associated with stem cell-like tumour cells, which have been proposed to be the active source of metastatic spread in primary tumours (Wicha and Hayes, 2011). Current models suggest that the invasive phenotype appears to be associated with an epithelial-mesenchymal transition (EMT), which enables the detachment of tumour cells from a primary site, and migration. The reverse process of the mesenchymal-epithelial transition (MET) might have a crucial role in the further steps of metastasis when CTC settle down in distant organs and establish metastasis. Nevertheless, the exact mechanisms and interplay of EMT and MET are only partially understood and their relevance in cancer patients is unclear. A subset of CTC shows EMT and stem cell characteristics, and the currently used detection methods for CTC are not efficient in identifying these CTC subtypes. Research groups have just started to apply EMT-related markers in their studies of CTC in cancer patients. In a recent review, the current state of investigations on CTC in the context of research on EMT/MET is discussed in detail (Bednarz-Knoll et al, 2012).

Recent data indicate that a major proportion of CTC of MBC patients shows EMT and tumour stem cell characteristics (Aktas et al, 2009). CTC expressing TWIST and vimentin were identified in patients with metastatic disease and in early BC patients (Kallergi et al, 2011). The high incidence of these cells in metastatic disease compared with cells in early-stage $\mathrm{BC}$ strongly supports the notion that EMT is involved in the metastatic potential of CTC. A recent study on the expression of EMT markers and ALDH1 in CTC from primary BC patients showed that a subset of primary BC patients shows EMT and stem cell characteristics, and that the currently used detection methods for CTC are not efficient to identify a subtype of CTC, which underwent EMT (Kasimir-Bauer et al, 2012).

Recent data indicate that patients with HER-2-positive MBC have CTC undergoing EMT (Giordano et al, 2012). Wicha's group (Ithimakin et al, 2013) has very recently shown that HER-2 is selectively expressed in and regulates self-renewal of the cancer stem cell (CSC) population in ER $(+)$ and HER-2-negative luminal BCs. They suggest that the clinical efficacy of adjuvant trastuzumab may relate to the ability of this agent to target the CSC population in a process that does not require HER-2 gene amplification (Ithimakin et al, 2013). The same group very recently demonstrated that trastuzumab resistance may be mediated by an IL- 6 inflammatory loop that leads to expansion of the CSC population, and suggested that blocking this loop may provide alternative strategy to overcome trastuzumab resistance (Korkaya et al, 2012). These findings can have significant clinical implications in the near future, as they support a CSC model in which maximal clinical benefit is achieved when CSC-targeting agents are administered in the adjuvant setting.

Very recently, Yu et al (2013) have shown by serial monitoring of CTC in patients with BC that these cells simultaneously expressed mesenchymal and epithelial markers, and that mesenchymal cells expressing known EMT regulators, including transforming growth factor- $\beta$ pathway components and the FOXC1 transcription factor, were associated with disease progression. Surprisingly, in this study only $41 \%$ of MBC patients were CTC-positive (which is lower than the EpCAM-based CellSearch), although this assay detected CTC with an epithelial and mesenchymal phenotype.

Although EMT is associated with a gain of stem cell-like behaviour and is linked to the CSC concept, it is still a matter of debate how subsequent MET fits into the metastatic process and whether an MET is essential. Brabletz, 2012 has recently proposed two principle types of metastatic progression: (a) phenotypic plasticity involving transient EMT-MET processes and (b) intrinsic genetic alterations keeping cells in an EMT and stemness state.

Dormant DTCs seem to be characterised by a different biology than that of the primary tumours and overt metastasis. Targeting these cells is very crucial; however, our understanding of their biology is highly limited. Aguirre-Ghiso et al (2013) has recently stated that 'bedside clinical management of dormant disease will be a reality only after rigorous understanding of its molecular and cellular basis'.

\section{CLINICAL CHALLENGES}

Molecular characterisation of a single CTC holds considerable promise for predictive biomarker assessment and to explore CTC heterogeneity. The application of extremely powerful nextgeneration sequencing (NGS) technologies in the area of CTC molecular characterisation in combination with reliable single CTC isolation opens new frontiers. Powell et al (2012) demonstrated a high heterogeneity of CTC even among the same individuals by performing high-dimensional single CTC profiling, and directly measuring high-dimensional gene expression in individual CTC without the common practice of pooling such cells. Peeters et al (2013) recently evaluated a new method, the DEPArray system, that allows the dielectrophoretic manipulation and isolation of single CTC and $100 \%$ purified groups of CTC from pre-enriched blood samples, and explored the feasibility of their molecular characterisation. They have shown that they could obtain reliable gene expression profiles from single cells and groups of up to 10 cells.

NGS technologies have revealed that intratumour heterogeneity may foster tumour evolution and adaptation, and hinder personalised-medicine strategies that depend on results from single tumour-biopsy samples (Gerlinger et al, 2012). However, the small number of CTC reduces this complexity and could possibly provide a better picture for individualised treatments. Very recently, Heitzer et al (2013) performed the first comprehensive genomic profiling of CTC in patients with stage IV colorectal carcinoma using array-CGH and NGS. Mutations in known driver genes found in the primary tumour and metastasis were also detected in corresponding CTC. Mutations that were initially exclusively present in CTC were found by additional deep sequencing to be present at subclonal level in the primary tumours and metastases from the same patient (Heitzer et al, 2013).

Polzer and Klein (2013), based on numerous findings, propose that genetic heterogeneity and various cellular states may account for differences in drug response in early compared with that in late systemic cancer. Resistant cancer cell types may be predominant in MRD, whereas in metastatic disease abundant sensitive cells initially respond. In MRD, intrinsically unresponsive dormant or stem-like cells may confer resistance, whereas in manifest metastasis acquired drug resistance becomes increasingly important. They propose that we should eventually adjust our research foci away from the analysis of the primary tumours towards a direct analysis of the target cells of adjuvant therapies, the disseminated cancer cells and their evolutionary trajectories. Polzer and Klein (2013).

\section{CONCLUSIONS}

There is increasing evidence for the potential benefits of using CTC detection in future clinical practice. According to numerous clinical studies, there is clear evidence for long-term persistence 
of CTC in BC, while their presence is significantly associated with poorer survival in both early and MBC. CTC are often resistant to chemotherapy and hormone therapy, whereas they can be effectively targeted by biological therapies. The very recent example of administration of trastuzumab in HER-2-negative early BC, which was shown to eliminate therapy-resistant CTC and prolong DFS, points towards near-future applications of more individualised treatment strategies based on the molecular characterisation of CTC with improved efficacy and less side effects.

CTC analysis has the unique potential to offer a minimally invasive 'liquid biopsy' sample, easily obtainable at multiple time points during disease history, thus providing valuable information on the very early assessment of treatment efficacy and helping towards establishing individualised treatment approaches that will improve efficacy with less cost and side effects for BC patients.

In conclusion, the continuous progress of basic research towards better understanding of the molecular mechanisms leading to metastasis in combination with the molecular characterisation of CTC at the single-cell level holds a great promise for a successful individualised treatment of $\mathrm{BC}$ patients in the near future.

\section{CONFLICT OF INTEREST}

We apologise to all colleagues whose work could not be cited because of space limitations.

\section{REFERENCES}

Aguirre-Ghiso JA, Bragado P, Sosa MS (2013) Metastasis awakening: targeting dormant cancer. Nat Med 19(3): 276-277.

Aktas B, Tewes M, Fehm T, Hauch S, Kimmig R, Kasimir-Bauer S (2009) Stem cell and epithelial-mesenchymal transition markers are frequently overexpressed in circulating tumor cells of metastatic breast cancer patients. Breast Cancer Res 11(4): R46.

Alix-Panabières C, Pantel K (2013) Circulating tumor cells: liquid biopsy of cancer. Clin Chem 59(1): 110-118.

Androulakis N, Agelaki S, Perraki M, Apostolaki S, Bozionelou V, Pallis A, Kalbakis K, Xyrafas A, Mavroudis D, Georgoulias V (2012) Clinical relevance of circulating CK-19mRNA-positive tumour cells before front-line treatment in patients with metastatic breast cancer. $\mathrm{Br} J$ Cancer 106(12): 1917-1925.

Banys M, Gruber I, Krawczyk N, Becker S, Kurth R, Wallwiener D, Jakubowska J, Hoffmann J, Rothmund R, Staebler A, Fehm T (2012) Hematogenous and lymphatic tumor cell dissemination may be detected in patients diagnosed with ductal carcinoma in situ of the breast. Breast Cancer Res Treat 131(3): 801-808.

Bednarz-Knoll N, Alix-Panabières C, Pantel K (2012) Plasticity of disseminating cancer cells in patients with epithelial malignancies. Cancer Metastasis Rev 31(3-4): 673-687.

Benoy IH, Elst H, Philips M, Wuyts H, Van Dam P, Scharpé S, Van Marck E, Vermeulen PB, Dirix LY (2006) Real-time RT-PCR detection of disseminated tumour cells in bone marrow has superior prognostic significance in comparison with circulating tumour cells in patients with breast cancer. Br J Cancer 94(5): 672-680.

Bidard FC, Mathiot C, Delaloge S, Brain E, Giachetti S, de Cremoux P, Marty M, Pierga JY (2010) Single circulating tumor cell detection and overall survival in nonmetastatic breast cancer. Ann Oncol 21(4): 729-733.

Bidard FC, Fehm T, Ignatiadis M, Smerage JB, Alix-Panabières C, Janni W, Messina C, Paoletti C, Müller V, Hayes DF, Piccart M, Pierga JY (2013) Clinical application of circulating tumor cells in breast cancer: overview of the current interventional trials. Cancer Metastasis Rev 32(1-2): 179-188.

Brabletz T (2012) To differentiate or not-routes towards metastasis. Nat Rev Cancer 12(6): 425-436.

Braun S, Pantel K, Müller P, Janni W, Hepp F, Kentenich CR, Gastroph S, Wischnik A, Dimpfl T, Kindermann G, Riethmüller G, Schlimok G (2000)
Cytokeratin-positive cells in the bone marrow and survival of patients with stage I, II, or III breast cancer. N Engl J Med 342(8): 525-533.

Cristofanilli M, Budd GT, Ellis MJ, Stopeck A, Matera J, Miller MC, Reuben JM, Doyle GV, Allard WJ, Terstappen LW, Hayes DF (2004) Circulating tumor cells, disease progression, and survival in metastatic breast cancer. $N$ Engl J Med 351(8): 781-791.

Fehm T, Hoffmann O, Aktas B, Becker S, Solomayer EF, Wallwiener D, Kimmig R, Kasimir-Bauer S (2009) Detection and characterization of circulating tumor cells in blood of primary breast cancer patients by RT-PCR and comparison to status of bone marrow disseminated cells. Breast Cancer Res 11(4): R59.

Fehm T, Müller V, Aktas B, Janni W, Schneeweiss A, Stickeler E, Lattrich C, Löhberg CR, Solomayer E, Rack B, Riethdorf S, Klein C, Schindlbeck C, Brocker K, Kasimir-Bauer S, Wallwiener D, Pantel K (2010) HER2 status of circulating tumor cells in patients with metastatic breast cancer: a prospective, multicenter trial. Breast Cancer Res Treat 124(2): 403-412.

Georgoulias V, Bozionelou V, Agelaki S, Perraki M, Apostolaki S, Kallergi G, Kalbakis K, Xyrafas A, Mavroudis D (2012) Trastuzumab decreases the incidence of clinical relapses in patients with early breast cancer presenting chemotherapy-resistant CK-19mRNA-positive circulating tumor cells: results of a randomized phase II study. Ann Oncol 23(7): 1744-1750.

Gerlinger M, Rowan AJ, Horswell S, Larkin J, Endesfelder D, Gronroos E, Martinez P, Matthews N, Stewart A, Tarpey P, Varela I, Phillimore B, Begum S, McDonald NQ, Butler A, Jones D, Raine K, Latimer C, Santos CR, Nohadani M, Eklund AC, Spencer-Dene B, Clark G, Pickering L, Stamp G, Gore M, Szallasi Z, Downward J, Futreal PA, Swanton C (2012) Intratumor heterogeneity and branched evolution revealed by multiregion sequencing. $N$ Engl J Med 366(10): 883-892.

Giordano A, Gao H, Anfossi S, Cohen E, Mego M, Lee BN, Tin S, De Laurentiis M, Parker CA, Alvarez RH, Valero V, Ueno NT, De Placido S, Mani SA, Esteva FJ, Cristofanilli M, Reuben JM (2012) Epithelialmesenchymal transition and stem cell markers in patients with HER2-positive metastatic breast cancer. Mol Cancer Ther 11(11): 2526-2534.

Giuliano M, Giordano A, Jackson S, Hess KR, De Giorgi U, Mego M, Handy BC, Ueno NT, Alvarez RH, De Laurentiis M, De Placido S, Valero V, Hortobagyi GN, Reuben JM, Cristofanilli M (2011) Circulating tumor cells as prognostic and predictive markers in metastatic breast cancer patients receiving first-line systemic treatment. Breast Cancer Res 13(3): R67.

Heitzer E, Auer M, Gasch C, Pichler M, Ulz P, Hoffmann EM, Lax S, Waldispuehl-Geigl J, Mauermann O, Lackner C, Höfler G, Eisner F, Sill H, Samonigg H, Pantel K, Riethdorf S, Bauernhofer T, Geigl JB, Speicher MR (2013) Complex tumor genomes inferred from single circulating tumor cells by array-CGH and next-generation sequencing. Cancer Res 73(10): 2965-2975.

Ignatiadis M, Rothé F, Chaboteaux C, Durbecq V, Rouas G, Criscitiello C, Metallo J, Kheddoumi N, Singhal SK, Michiels S, Veys I, Rossari J, Larsimont D, Carly B, Pestrin M, Bessi S, Buxant F, Liebens F, Piccart M, Sotiriou C (2011) HER2-positive circulating tumor cells in breast cancer. PLoS One 6(1): e15624.

Ithimakin S, Day KC, Malik F, Zen Q, Dawsey SJ, Bersano-Begey TF, Quraishi AA, Ignatoski KW, Daignault S, Davis A, Hall CL, Palanisamy N, Heath AN, Tawakkol N, Luther TK, Clouthier SG, Chadwick WA, Day ML, Kleer CG, Thomas DG, Hayes DF, Korkaya H, Wicha MS (2013) HER2 drives luminal breast cancer stem cells in the absence of HER2 amplification: implications for efficacy of adjuvant trastuzumab. Cancer Res 73(5): 1635-1646.

Kallergi G, Papadaki MA, Politaki E, Mavroudis D, Georgoulias V, Agelaki S (2011) Epithelial to mesenchymal transition markers expressed in circulating tumour cells of early and metastatic breast cancer patients. Breast Cancer Res 13(3): R59.

Kasimir-Bauer S, Hoffmann O, Wallwiener D, Kimmig R, Fehm T (2012) Expression of stem cell and epithelial-mesenchymal transition markers in primary breast cancer patients with circulating tumor cells. Breast Cancer Res 14(1): R15.

Korkaya H, Kim GI, Davis A, Malik F, Henry NL, Ithimakin S, Quraishi AA, Tawakkol N, D'Angelo R, Paulson AK, Chung S, Luther T, Paholak HJ, Liu S, Hassan KA, Zen Q, Clouthier SG, Wicha MS (2012) Activation of an IL6 inflammatory loop mediates trastuzumab resistance in HER2 + breast cancer by expanding the cancer stem cell population. Mol Cell 47(4): 570-584. 
Klein CA. Parallel progression of primary tumours and metastases (2009) Nat Rev Cancer 9(4): 302-312.

Lianidou ES, Markou A, Strati A (2012) Molecular characterization of circulating tumor cells in breast cancer: challenges and promises for individualized cancer treatment. Cancer Metastasis Rev 31(3-4): 663-671.

Ligthart ST, Bidard FC, Decraene C, Bachelot T, Delaloge S, Brain E, Campone M, Viens P, Pierga JY, Terstappen LW (2013) Unbiased quantitative assessment of Her-2 expression of circulating tumor cells in patients with metastatic and non-metastatic breast cancer. Ann Oncol 24(5): 1231-1238.

Lucci A, Hall CS, Lodhi AK, Bhattacharyya A, Anderson AE, Xiao L, Bedrosian I, Kuerer HM, Krishnamurthy S (2012) Circulating tumour cells in non-metastatic breast cancer: a prospective study. Lancet Oncol 13(7): 688-695.

Muller V, Riethdorf S, Rack B, Janni W, Fasching P, Solomayer E, Aktas B, Kasimir-Bauer S, Pantel K, Fehm T. Study Group TD (2012) Prognostic impact of circulating tumor cells assessed with the CellSearch AssayTM and AdnaTest BreastTM in metastatic breast cancer patients: the DETECT study. Breast Cancer Res 14(4): R118.

Pantel K, Alix-Panabières C, Riethdorf S. Cancer micrometastases (2009) Nat Rev Clin Oncol 6(6): 339-351.

Pantel K, Brakenhoff RH. Dissecting the metastatic cascade (2004) Nat Rev Cancer 4(6): 448-456.

Parkinson DR, Dracopoli N, Petty BG, Compton C, Cristofanilli M, Deisseroth A, Hayes DF, Kapke G, Kumar P, JSh Lee, Liu MC, McCormack R, Mikulski S, Nagahara L, Pantel K, Pearson-White S, Punnoose EA, Roadcap LT, Schade AE, Scher HI, Sigman CC, Kelloff GJ (2012) Considerations in the development of circulating tumor cell technology for clinical use. J Transl Med 10: 138.

Peeters DJ, De Laere B, Van den Eynden GG, Van Laere SJ, Rothé F, Ignatiadis M, Sieuwerts AM, Lambrechts D, Rutten A, van Dam PA, Pauwels P, Peeters M, Vermeulen PB, Dirix LY (2013) Semiautomated isolation and molecular characterization of single or highly purified tumor cells from CellSearch enriched blood samples using dielectrophoretic cell sorting. Br J Cancer 108(6): 1358-1367.

Pierga JY, Hajage D, Bachelot T, Delaloge S, Brain E, Campone M, Diéras V, Rolland E, Mignot L, Mathiot C, Bidard FC (2012) High independent prognostic and predictive value of circulating tumor cells compared with serum tumor markers in a large prospective trial in first-line chemotherapy for metastatic breast cancer patients. Ann Oncol 23(3): 618-624.

Polzer B, Klein CA (2013) Metastasis awakening: the challenges of targeting minimal residual cancer. Nat Med 19(3): 274-275.

Powell AA, Talasaz AH, Zhang H, Coram MA, Reddy A, Deng G, Telli ML, Advani RH, Carlson RW, Mollick JA, Sheth S, Kurian AW, Ford JM, Stockdale FE, Quake SR, Pease RF, Mindrinos MN, Bhanot G, Dairkee SH, Davis RW, Jeffrey SS (2012) Single cell profiling of circulating tumor cells: transcriptional heterogeneity and diversity from breast cancer cell lines. PLoS One 7(5): e33788.

Punnoose EA, Atwal SK, Spoerke JM, Savage H, Pandita A, Yeh RF, Pirzkall A, Fine BM, Amler LC, Chen DS, Lackner MR (2010) Molecular biomarker analyses using circulating tumor cells. PLoS One 5(9): e12517.

Rack B, Bock C, Andergassen U, Doisneau-Sixou S (2012) Hormone receptor status, erbB2 expression and cancer stem cell characteristics of circulating tumor cells in breast cancer patients. Histol Histopathol 27(7): 855-864.

Riethdorf S, Müller V, Zhang L, Rau T, Loibl S, Komor M, Roller M, Huober J, Fehm T, Schrader I, Hilfrich J, Holms F, Tesch H, Eidtmann H, Untch M, von Minckwitz G, Pantel K (2010) Detection and HER2 expression of circulating tumor cells: prospective monitoring in breast cancer patients treated in the neoadjuvant GeparQuattro Trial. Clin Cancer Res 16: 2634-2645.

Saloustros E, Perraki M, Apostolaki S, Kallergi G, Xyrafas A, Kalbakis K, Agelaki S, Kalykaki A, Georgoulias V, Mavroudis D (2011) Cytokeratin-19
mRNA-positive circulating tumor cells during follow-up of patients with operable breast cancer: prognostic relevance for late relapse. Breast Cancer Res 13(3): R60.

Sänger N, Effenberger KE, Riethdorf S, Van Haasteren V, Gauwerky J, Wiegratz I, Strebhardt K, Kaufmann M, Pantel K (2011) Disseminated tumor cells in the bone marrow of patients with ductal carcinoma in situ. Int J Cancer 129(10): 2522-2526.

Sieuwerts AM, Mostert B, Bolt-de Vries J, Peeters D, de Jongh FE, Stouthard JM, Dirix LY, van Dam PA, Van Galen A, de Weerd V, Kraan J, van der Spoel P, Ramírez-Moreno R, van Deurzen CH, Smid M, Yu JX, Jiang J, Wang Y, Gratama JW, Sleijfer S, Foekens JA, Martens JW (2011) mRNA and microRNA expression profiles in circulating tumor cells and primary tumors of metastatic breast cancer patients. Clin Cancer Res 17(11): $3600-3618$.

Strati A, Kasimir-Bauer S, Markou A, Parisi C, Lianidou ES (2013) Comparison of three molecular assays for the detection and molecular characterization of circulating tumor cells in breast cancer. Breast Cancer Res 15(2): R20.

Tewes M, Aktas B, Welt A, Mueller S, Hauch S, Kimmig R, Kasimir-Bauer S (2009) Molecular profiling and predictive value of circulating tumor cells in patients with metastatic breast cancer: an option for monitoring response to breast cancer related therapies. Breast Cancer Res Treat 115(3): 581-590.

Wicha MS, Hayes DF (2011) Circulating tumor cells: not all detected cells are bad and not all bad cells are detected. J Clin Oncol 29(12): 1508-1511.

Van der Auwera I, Peeters D, Benoy IH, Elst HJ, Van Laere SJ, Prové A, Maes H, Huget P, van Dam P, Vermeulen PB, Dirix LY (2010) Circulating tumour cell detection: a direct comparison between the CellSearch System, the AdnaTest and CK-19/mammaglobin RT-PCR in patients with metastatic breast cancer. $\mathrm{Br} J$ Cancer 102(2): 276-284.

Zhang L, Riethdorf S, Wu G, Wang T, Yang K, Peng G, Liu J, Pantel K (2012) Meta-analysis of the prognostic value of circulating tumor cells in breast cancer. Clin Cancer Res 18(20): 5701-5710.

Yu M, Bardia A, Wittner BS, Stott SL, Smas ME, Ting DT, Isakoff SJ, Ciciliano JC, Wells MN, Shah AM, Concannon KF, Donaldson MC, Sequist LV, Brachtel E, Sgroi D, Baselga J, Ramaswamy S, Toner M, Haber DA, Maheswaran S (2013) Circulating breast tumor cells exhibit dynamic changes in epithelial and mesenchymal composition. Science 339(6119): 580-584.

Xenidis N, Ignatiadis M, Apostolaki S, Perraki M, Kalbakis K, Agelaki S, Stathopoulos EN, Chlouverakis G, Lianidou E, Kakolyris S, Georgoulias V, Mavroudis D (2009) Cytokeratin-19 mRNA-positive circulating tumor cells after adjuvant chemotherapy in patients with early breast cancer. $J$ Clin Oncol 27(13): 2177-2184.

Xenidis N, Markos V, Apostolaki S, Perraki M, Pallis A, Sfakiotaki G, Papadatos-Pastos D, Kalmanti L, Kafousi M, Stathopoulos E, Kakolyris S, Mavroudis D, Georgoulias V (2007) Clinical relevance of circulating CK-19 mRNA-positive cells detected during the adjuvant tamoxifen treatment in patients with early breast cancer. Ann Oncol 18(10): 1623-1631.

Xenidis N, Perraki M, Kafousi M, Apostolaki S, Bolonaki I, Stathopoulou A, Kalbakis K, Androulakis N, Kouroussis C, Pallis T, Christophylakis C, Argyraki K, Lianidou ES, Stathopoulos S, Georgoulias V, Mavroudis D (2006) Predictive and prognostic value of peripheral blood cytokeratin-19 mRNA-positive cells detected by real-time polymerase chain reaction in node-negative breast cancer patients. J Clin Oncol 24(23): 3756-3762.

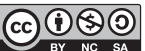

This work is licensed under the Creative Commons Attribution-NonCommercial-Share Alike 3.0 Unported License. To view a copy of this license, visit http://creativecommons. org/licenses/by-nc-sa/3.0/ 